\title{
Divorce Reform in Egypt and Morocco: Men and Women Navigating Rights and Duties
}

\author{
Nadia Sonneveld \\ Radboud Universiteit \\ nadia.sonneveld@gmail.com
}

\begin{abstract}
This essay focuses on recent divorce reforms in Egypt (2000) and Morocco (2004), with equal attention to the positions of men and women who end their marriages. Whereas in Egypt, non-consensual, no-fault divorce reform $(k h u l)$ is open only to women, in Morocco, another form of non-consensual, no-fault divorce, shiqāq, is open to both women and men, with men using it almost as frequently as women. Based on legal analysis and anthropological fieldwork, I consider first how men and women navigate rights and duties in divorce and then examine the differences between the two countries in the way men and women try to obtain divorce. I conclude that when both men and women are given opportunities for non-consensual, no fault divorce, highly genderspecific divorce regimes, such as the țalāq and tațlìq, quickly lose their popularity.
\end{abstract}

\section{Keywords}

divorce - reform - khul' - shiqāq - țalāq - Egypt - Morocco

* The research on which this article is based was made possible through a generous grant from the Netherlands Organisation for Scientific Resesearch (NwO) for the research project "Shari'a in Revolution: An Assessment of the Attitude of Moroccan Justice Seekers and Legal Professionals toward the Mudawwana." The author would also like to thank the Hillary Clinton Center for Women's Empowerment of Al-Akhawayn University in Ifrane, Morocco, for providing the institutional affiliation and help needed to conduct research in Morocco. 


\section{Introduction}

The reform of codified divorce law has developed in stages throughout most of the Muslim world. During the first stage, legislators and ruling elites introduced procedural constraints that limited a husband's right to a non-consensual and no-fault divorce through talāq. ${ }^{1}$ Simultaneously, the grounds on which a woman may initiate a fault-based divorce (tattliq ) were expanded, mostly in countries where the Hanafi law school is dominant (Welchman 2007: 109; Kruiniger 2015: 87). In Egypt, for example, a repudiation pronounced by a husband who is intoxicated or under duress was declared ineffective in 1929 (Article 1 of Personal Status Law no. 25/1929). Additionally, the triple taläq, in which the husband utters the repudiation three times in one sitting, counted, and still counts, as only one (ibid.: Article 3). Before the initial codification of Personal Status Law (hereinafter PSL) in 1920, Egyptian Muslim women could only request a non-consensual divorce on the grounds allowed by the Hanafi law school, i.e., the husband's impotence, prolonged absence (i.e. if go years have elapsed since his birth), or apostasy. The PSLs of 1920 and 1929 gave women several new grounds for divorce. These were, and still are, the husband's absence without legitimate cause for a period exceeding one year (Article 12 of PSL no. 25/1929); his imprisonment for a period exceeding three years (Article 14 of PSL no. 25/1929); his mental illness or grave and incurable sickness, about which the wife had no knowledge at the time of the marriage (Article 9 of PSL no. $25 / 1929) ;{ }^{2}$ his failure to provide maintenance; or his harming of his wife (Article 6 of PSL no. 25/1929; amended by PSL no. 100/1985).

Morocco's first codification of PSL in 1957-1958 resulted in similar restrictions on a husband's right to taläq. A repudiation pronounced during menstruation, extreme anger, or linked to an oath or conditions is ineffective. As in Egypt, threefold-repudiations count as one (Buskens 2003: 74). Like their Egyptian counterparts, Moroccan women were given a number of grounds for divorce. This is not surprising because the Maliki law school, which is officially adopted in Morocco, is liberal in granting women judicial divorce as compared to the other three Sunni law schools. Maliki law has served as a basis for reform in many other Muslim-majority countries, including Egypt.

The Egyptian and Moroccan divorce reforms resemble reforms introduced by legislators and ruling elites in many other Muslim-majority countries, where the prevailing Sunni understanding of taläq and tațliq was incorporated into

1 In this essay, 'no-fault' refers to a divorce in which fault is not a requirement to obtain the divorce.

2 Grave and incurable sickness does not include impotence, but the 1929 PSL states that the Hanafi doctrine applies in cases not covered by the 1929 PSL. For this reason, judges continued to issue divorces on the basis of impotence (Shaham 1997: 114). 
national laws. ${ }^{3}$ There have been a few exceptions to this pattern. In Turkey, shari $a$-based family law was replaced in 1926 by the Swiss Civil Code of 1907, including its law of personal status (Ansay and Wallace, Jr. 2005: 9). Following Tunisia's independence from France in 1956, President Habib Bourguiba introduced a law of personal status that gave men and women equal divorce rights. In Indonesia, the Marriage Law of 1974 - applicable to Muslims and non-Muslims - introduced, first, judicial divorce for men and women, and, second, the same divorce grounds for men and women, including irreconcilable marital discord (shiqāq). Likewise, in Pakistan in 1967, the Supreme Court endorsed a new understanding of khul' as a non-consensual divorce on the demand of the wife (Khurshid Bibi v. Muhammad Amin, PLD 1967 SC 97).

In Islamic law, khul' is technically a divorce by the husband in return for compensation paid to him by the wife. According to Hanafi doctrine, a man or a woman may initiate a khul' divorce (Zantout 2006: 4). However, in Pakistan and elsewhere, more women do so than men, usually in return for (financial) compensation, to which the husband must consent. The ${ }_{1967}$ Pakistani ruling was pioneering in that, first, the husband's consent was no longer a legal prerequisite, and, second, a woman did not need to show cause in court. While this ruling considerably improved the legal position of women inside Pakistan, it received little attention outside the country, despite the fact that the reform placed Pakistan at the forefront of what Welchman calls a "third phase" of divorce reform in Arab countries. In this third phase, legislators tried to temper a husband's power of taläq by introducing non-consensual, no-fault divorce (2007: 109). In Arab countries, this phase started in Egypt in January 2000 with the introduction of a divorce procedure for women called khul'. This form of khul' did not require the consent of the husband, neither did it require the wife to show cause in court.

The introduction of khul' provoked heated debates both inside and outside Egypt (Sonneveld 2012: Chapters 2 and 3). Other Arab states followed the Egyptian example by introducing similar laws, including Jordan in 2001 (Welchman 2007: 116) and, to different degrees, Algeria (2005), Palestine (2005), Qatar (2006), and the United Arab Emirates (2005) (ibid.: 119). In Morocco, Benyahya, cited in Welchman (2007: 120), found that women's rights organisations also requested the inclusion of non-consensual khul' divorce. The Moroccan legislature declined this request but gave women the right to a new form of nonconsensual, no-fault divorce through a procedure called shiqāq. In Morocco, shiqāq refers to a divorce based on irreconcilable differences; such a divorce may be initiated by either spouse. If two court-appointed arbitrators are

3 A few examples are: Syria, Lebanon, Gaza, Pakistan, and Sudan. For details, see Welchman (2007). 
unable to reconcile the spouses, the court will grant the divorce (Articles 94-97 Family Law 2004, hereafter FL 2004). ${ }^{4}$

Along with rights come obligations. Typically, țalāq entails not only a husband's right to dissolve the marital union on a no-fault basis and without the consent of his wife, but also his duty to pay the deferred dower, waiting-period maintenance, and sometimes also mut' $^{\prime} a$ (compensation that the wife receives if the judge does not hold her responsible for the divorce). ${ }^{5}$ Similarly, khul' and shiqāq encompass not only a wife's right to demand a no-fault and non-consensual divorce but also her duty to relinquish (some) outstanding debts that her husband owes her and, in Egypt, to compensate her husband by returning the șadāq (dower) to him. A Moroccan woman compensates her husband if he requests it and is able to prove that she is responsible for the marital discord.

In this essay, I focus on Egypt and Morocco, the two Muslim-majority countries that arguably introduced the most extensive divorce reforms of the $2000 \mathrm{~s}$. My goal is to gain a better understanding of both women's and men's rights and duties with respect to divorce. I pose the following questions: first, how do men and women navigate rights and duties in divorce? Second, are there differences between the two countries regarding the way men and women try to obtain divorce? The following analysis is based on qualitative research methods, in different time periods, and I therefore do not draw any general conclusions.

This essay is based on data gathered through formal and informal meetings with judges (male and female) and litigants (male and female), in addition to the analysis of legal documents in Egypt (2003-2005) and Morocco (2014-2015). In Egypt, I interviewed fifteen family law judges (all male) in five courthouses in Cairo. In Morocco, I interviewed 61 family law judges ( 25 women and 36 men) in nine courthouses across the country.

The part of my research project dealing with litigants was based on informal meetings and discussions, fleeting comments, observations, and chance encounters with Egyptians and Moroccans from all walks of life. In Egypt, I spoke to more than 100 women who were involved in divorce (mostly khul') cases as litigants, lawyers, or mediators. Sixteen of these meetings were recorded and conducted in a formal and structured manner, while the others were informal and loosely structured meetings. Likewise, most meetings in Morocco with women litigants were informal. Fifty-three women with marital problems were interviewed in a formal and structured manner, either inside or in front of the

4 Al-nizā $\bar{a}^{\prime} w a-l-s h i q \bar{a} q$ as a ground for arbitration that may lead to separation of the spouses appeared already in the 1917 Ottoman Family Rights Law.

5 If there are children, a husband must also pay maintenance for them and, in some countries, provide the children and their mother with adequate housing. See Welchman (2007: 130-31). 
courthouse. In both countries, I spoke with numerous men involved in divorce cases, either as husbands, family members, or lawyers. As with the women, most data were gathered informally. The presence of my husband considerably facilitated access to men. In his presence, I could meet with men without raising any suspicion and at the same time hear these men argue about marriage and divorce in general. The subject of marriage and divorce often aroused strong emotions, as many of these men were either preparing for marriage or dealing with a difficult or failed marriage. The meetings with men in Egypt were all informal, while in Morocco my research assistants conducted structured interviews with twenty-five men, either inside or in front of the courthouse.

I also analysed Egyptian and Moroccan legal documents, such as the family law codes, court records, case law, official documents that explain the spirit of the law, and the annotations of legal professionals. These documents are written in Arabic or in French.

Sections one and two of this essay present an overview of legal regulations dealing with divorce in Egypt and Morocco, respectively. In contrast to most other studies, this essay focuses not only on rights, but also on obligations pertaining to both men and women. Section three demonstrates how legal rules are applied in Egyptian and Moroccan courts. Using this data, I respond to the two main questions that are central to this essay.

\section{Possibilities for Divorce in Egypt}

Prior to the introduction of non-consensual khul' in 2000, Egyptian legal practice recognised three forms of dissolution. ${ }^{6}$ No-fault dissolution at the demand of a husband (țalāq) and wife-initiated judicial divorce on the basis of various legally stipulated grounds (tatli $q$ ) were both covered by codified Personal Status Law. Divorce by agreement was not codified and when litigants sought to formally register such a divorce, judges invoked Hanafi doctrine or the unofficial Qadri Basha Code. ${ }^{7}$ Divorce by agreement took two forms: delegated repudiation, in which a husband delegates the right of repudiation to his wife, ${ }^{8}$

6 The death or conversion of one of the spouses also leads to the dissolution and nullity, respectively, of marriage.

7 Published in 1875 by the Egyptian government, the Qadri Basha Code was a compilation of Hanafi doctrine in personal status matters (Shaham 1997: 14). It never gained official approval but was and is widely used by Egyptian judges.

8 Egyptian lawyers and judges call this procedure ișma. In cases of ișma, a wife registers the right to delegated repudiation in the marriage contract. 
and divorce by mutual consent through $k h u l l^{9}{ }^{9}$ While delegated repudiation

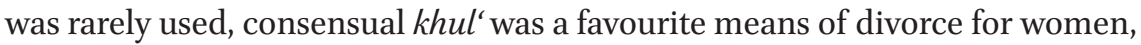
as was the case in medieval Cairo, Damascus and Jerusalem (Rapoport 2005), Ottoman Egypt (Sonbol 1995), Istanbul (Zilfi 1997), Rumelia (present southeastern Europe) (Ivanova 1996), and Marinid Morocco (mid-thirteenth-midfifteenth century) (Admiral 2016: 21). ${ }^{10}$ In a study of decisions by the Egyptian shari ${ }^{-1} a$ courts between 1900 and 1955, Shaham found that fault-based divorces were rare, whereas divorces by mutual agreement were common (Shaham 1997: 106-07, 118-19). ${ }^{11}$

\section{Men's Divorce in Egypt: Rights and Duties}

Until the present, a Muslim husband in Egypt may pronounce the repudiation outside of court and needs only to register it with the ma'dhün (registrar) within thirty days of the date of pronunciation (Article 5 bis of PSL no. 100/1985). ${ }^{12}$ Non-registration of the repudiation does not render it invalid. A husband who repudiates his wife must compensate her by paying the deferred dower, waiting-period maintenance, and sometimes also mut'a. If there are children, a husband must also pay maintenance for them and provide the children and their mother with adequate housing. Since 200o, failure to pay maintenance may result in imprisonment for a period not to exceed thirty days (Article 76 bis of Law no. 91 of 2000) (Bernard-Maugiron 2004: 376). Since 1920, the codification of Personal Status Law in Egypt has given women more opportunities for non-consensual, fault-based divorce (tattīq) (in the 1920s and 1980s), and for non-consensual, no-fault based divorce $(\mathrm{khul}$ ) (in 2000). By contrast, options for divorce for Egyptian Muslim men have not increased, and are currently limited to talāq, a non-consensual, no-fault based divorce in which they must pay their wives the deferred dower, waiting-period maintenance, and, in some cases, a mut'a compensation, regardless of who was responsible for the marital breakup. Egyptian Muslim men do not have access to fault-based judicial divorce (El-Ehwany 2012: 55).

\section{Women's Divorce in Egypt: Rights and Duties}

As noted, since the codification of PSL in the 1920s, a woman has several grounds for a fault-based divorce in which she retains her financial rights, i.e.,

9 The Qadri Basha Code deals with delegated repudiation ('ișma) in Articles 26o-65 and with khul' in Articles 273-97 (Ebert 2010: 92-3, 96-102).

10 On the historical origins and practice of khul' in the Muslim world, see Sonneveld and Stiles (2016).

11 Only approximately 70 of the thousands of cases that Shaham studied were fault-based divorce cases.

12 "Bis" means two and refers to the inclusion of a new paragraph in an already existing law article. This is usually done to avoid renumbering the entire law. 
the deferred dower, waiting-period maintenance and, after 1979, mut' $a$ compensation. However, it is difficult for a woman to establish grounds for faultbased divorce. Until the promulgation of PSL no. 1/200o, unless she was unable to convince her husband to agree to a khul' by mutual consent, she had no choice but to remain in an unwanted marriage, as exemplified in the influential 1975 Egyptian film "Urīdu Ḥallan" (I Want a Solution), which was set during the administration of Egypt's second president, Gamal Abdel Nasser.

Notably, Nasser's socialist regime expanded women's rights in education and employment and gave women the right to vote in 1956. Changes in women's public rights were not accompanied by legal reform in the private sphere, however. For reasons that require further research, Nasser hesitated to reform the PSL. ${ }^{13}$ As a result, a husband was legally obligated to provide financial support for his wife, and his wife was obligated to obey him. This meant that a wife could not leave the house without her husband's permission, even if she was a minister in the government. Similarly, if a woman wanted a divorce, she was dependent on the consent of either her husband or a male judge (Egypt's first female judge was appointed in 2003. See Sonneveld and Tawfik 2015).

"Urīdu Hallan" tells the story of an upper-class Egyptian woman in a dysfunctional marriage who asks her husband to pronounce a talāq. As a professional with her own source of income, she does not want to claim any of her outstanding financial rights. When her husband refuses, she has no choice but to file a fault-based divorce on the ground of harm. After a four-year legal battle, the judges deny her request because, they argue, she did not present clear and convincing evidence of harm by her husband. Throughout the film, she searches for a solution in the form of khul': non-consensual, no-fault divorce upon the demand of the wife. She claims that Muslim women have this right based on a hadith in which a married woman approaches the Prophet, telling him that she cannot stand living with her husband, even though he is a religious man of good character. She fears that she will transgress the limits of God if she stays in this marriage. The Prophet asks her if she is willing to give up the garden that was her dower. She agrees, whereupon he orders the husband to pronounce the talāq.

The film had a great impact on Egyptian society and inspired women's rights activists to demand reform of PSL. These activisists played an important role in

13 Elsewhere I have argued that Egypt's defeat in the Six Day War of 1967, which was followed by an increase in religiousity and the growing popularity of the Muslim Brotherhood, made it difficult for Nasser to introduce reform of PSL (Sonneveld 2012: 23-4). Sezgin (2013: 172) argues that Nasser did not regard the reform of substantive PSL as important. However, a recent documentary establishes that Tunisian president Habib Bourguiba and Nasser met in Tunis in 1966, a year prior to the war. When Bourguiba asked Nasser what was preventing him from introducing PSL reforms similar to the Tunisian reforms, Nasser replied: “I can't” (Feminists Insha'allah 2014). 
helping draft a law for personal status reform, which then President Anwar Sadat introduced in 1979, during a parliamentary recess. This reform (cancelled in 1985 and replaced by PSL no. 100/1985) allows a woman to ask the court for divorce on the ground of shiqa $q$ (marital discord), even when arbitrators have concluded that she bears more responsibility for the discord then he does. She must, however, persist in her claim and persuade the judge that marital life has become impossible (Article 11 of PSL no. 100/1985) (Shaham 1997: 117). In the late 1990s, a group of seven women ("The Group of Seven"), successfully lobbied high-ranking figures in the Ministry of Justice and al-Azhar to redefine khul' as the right of a Muslim woman to non-consensual, no-fault divorce (see Shaham 1999; Singerman 2005). Their efforts provoked much public debate, but in January 2000 a new procedural law on personal status was accepted by Parliament (Law no. 1/ 2000). This law includes a few substantive provisions, such as a woman's right to khul' divorce without the consent of her husband. The inclusion of non-consensual khul' divorce in the new PSL provoked much controversy in Egyptian society. Indeed, the law itself became known as "the khul' law." The legislature claimed that the law was consistent with the principles of Islam, as confirmed by the Sheikh of al-Azhar. But opponents claimed that non-consensual $\mathrm{khul}$ 'was an assault on religion -indeed, a Western invention introduced by the wife of the president in order to destabilise Egyptian family life. Opponents also argued that women were too emotional to be given the right to non-consensual, no-fault divorce and that they would use it for frivolous reasons, such as to marry another man (e.g. Sonneveld 2012: Chapter 2).

A closer look at the relevant khul' provision (Article 20) reveals that it includes two different forms of khul', one consensual ("The spouses may mutually agree to khul '...") and one initiated by the wife ("however, if they do not agree and the wife sues demanding it, and separates herself from her husband by giving up all her financial legal rights, and restores to him the șadāq (dower) he gave to her, then the court is to divorce her from him ..."). The right to nonconsensual, no-fault divorce is accompanied by certain obligations. A woman who requests a khul' divorce has the legal obligation to relinquish the outstanding financial rights (deferred dower, waiting-period maintenance, and mut'a compensation) to which she normally would be entitled in a talāq divorce. The law also specifies that she must return the "șadāq" (dower). Notwithstanding these financial consequences, khul' soon became very popular and within a year it was more often requested than the different forms of faultbased divorce, at least in Cairo and in courthouses north of Cairo (Sulīmān and Șalāh 2003: 18-28). This development did not go unnoticed in neighbouring countries, such as Jordan and Palestine, and in countries on the periphery of the Arabic-speaking world, notably Morocco and Algeria, where non-consensual, no-fault divorce was introduced in 2004 and 2005, respectively. 
One year after Morocco gained its independence from France in 1956, King Muhammad V codified personal status matters. The law adhered closely to Maliki doctrine. It was reformed for the first time in 1993 under King Hassan II, but the changes in women's divorce rights were minor (e.g. Buskens 2003; alAkhrīsī 2005; Ghamīja 2007). Hence, prior to the February 2004 reform, the legal right of a Moroccan woman to marry and divorce had remained almost unchanged for half a century. While a man could marry and divorce without the participation of a guardian $(w \bar{a} l \bar{\imath})$, a woman needed the consent of her marriage guardian to marry ${ }^{14}$ and the consent of her husband or a judge to divorce.

As in Egypt, there were three forms of divorce in Morocco prior to 2004:15 at the demand of the husband (talāq); on the initiative of the wife (țatlīq); and by mutual agreement. In contrast to Egypt, divorce by mutual agreement was codified and it could take the form of either tamlīk or khul'. Under tamlīk, a husband delegates the right of repudiation to his wife (Articles 44 and 67 PSL 1993; Article $89 \mathrm{FL} 2004$ ) - as in Egypt, this is rare in practice (Jordens-Cotran 2007:327). Under khul', a public notary ('adl, pl. 'udūl) is responsible for issuing the khul' divorce certificate, and the presence of the wife is mandatory (Jordens-Cotran 2007: 350).

There are only a few historical studies dealing with the ways in which men and women made use of Islamic law in Morocco. Most studies center on the Middle East, and especially Islamic law under the Ottoman Empire, with the exception of Admiral's recent study on women's engagement with Islamic law under the Marinid dynasty (mid-thirteenth -mid-fifteenth century). In the area of divorce, Admiral shows that men went to court when there was confusion about the effects of the talāq pronouncement (Admiral 2016: 120-22). Women had access to fault-based divorce but it was difficult to establish grounds for such a divorce, such as darar (harm). Consequently, women divorced through khul', which, in Marinid Morocco, required the consent of the husband. After they had secured divorce through khul', women would attempt to establish the grounds of harm retroactively in order to recover that part of

14 In the 1993 reform of the Moroccan PSL, the only exception to the rule that a woman needs the consent of her marriage guardian to marry and of her husband or a judge to divorce is a female orphan who has reached the legal age of majority (Jordens-Cotran 2007: 139).

15 As in Egypt, the death or conversion of one of the spouses also leads to the dissolution and nullity, respectively, of marriage. 
the dower (usually the deferred dower) that they had given up in the khul (Admiral 2016: 127-28).

\section{Men's Divorce in Morocco: Rights and Duties}

Although scholars frequently claim that the changes brought about by the 1993 PSL reform were small and symbolic (e.g. Buskens 2003; al-Akhrīsì 2005; Ghamija 2007), the right of a husband to divorce through țalāq was curtailed (Kruiniger 2015: 179). Apart from the fact that the 1993 P SL made it obligatory for a husband to ask a judge for permission to repudiate his wife, a wife was notified and summoned to appear in court and to provide information in order to allow the judge to establish post-divorce provisions. In țalāq divorces, the 1993 PSL also required the spouses to undergo mediation, and a judge would not issue the divorce certificate until the husband had paid a mandatory deposit at the court to be used to maintain his ex-wife and children following the divorce (Jordens-Cotran 2007: 310).

The taläq regulations included in the 2004 legislation are even more extensive than those in the 1993 PSL. For example, whereas prior to 2004 a husband had to pay the mandatory deposit at the court within a period, which, however, was not specified, after the 2004 reform he must pay the deposit within thirty days after the date on which mediation attempts failed; non-payment is considered a renunciation of his intention to repudiate (e.g. Kruiniger 2015: 179-80).

In the context of tightening legal regulations on taläq, the 2004 PSL reform simultaneously offers men a new way to divorce their wives on a non-consensual, no-fault basis. Through a procedure called tațlīq li'l-shiqāq, a man may request dissolution of the marital bond on the basis of marital discord (shiqāq), which he does not need to establish, but merely state in court. Like talāq, shiqāq requires the couple to undergo mediation. Whereas țalāq is revocable, a shiqāq divorce is irrevocable, which means that the wife becomes unavailable to her former husband unless they remarry and he pays her a new dower. ${ }^{16}$ Initially, a husband in a shiqāq divorce was not required to place the mandatory deposit at the court within thirty days from the date on which the meditation attempts failed. As will be explained below, this practice changed a few years later.

16 Although shiqāq in Morocco is irrevocable, a former wife does not need to consummate an intermediate marriage with another man (tahlīl) unless her husband has divorced her for a third time through shiqāq. 


\section{Women's Divorce in Morocco: Rights and Duties}

Before 2004, a Moroccan woman was entitled to a divorce without relinquishing her financial rights if she could prove one of several legally stipulated grounds, such as non-payment of maintenance by the husband, harm (physical and/or mental), and/or absence of the husband. As in other Muslim-majority countries, these grounds were difficult to establish in practice. In a study of judicial practice in two courts in Rabat and Salé, Mir-Hosseini notes that in the late 1980s, tațtī divorces comprised less than 3 percent of all divorce requests made by men and women (Mir-Hosseini 2000: 150). In 1987, more than onethird of all divorce requests in Rabat and Salé involved khul' by agreement (2000: 151). In such cases, the wife usually forfeited the right to maintenance for her children, despite the fact that such a concession was explicitly forbidden by article 60 of the PSL of 1993 (ibid.). A khul' agreement, however, was and still is conditional on the consent of the husband. Before 2004, if he refused, for whatever reason, to pronounce the talāq, and she could not show cause in court, the wife had no other choice but to remain in an unwanted marriage.

After 2000, Moroccan women's rights organisations asked the legislature to make the Egyptian understanding of khul' as a non-consensual, no-fault divorce available to Moroccan women. As mentioned, the Moroccan legislature declined this request (Welchman 2007: 120). Nevertheless, the FL 2004 articles that address khul'are almost identical to the Egyptian article on khul'. The first article (Article 115) states: "The spouses may mutually agree to khul", and Article 120 states: "... when the wife persists in her khul' request, and the husband does not consent, the wife may invoke the shiqāq procedure." Since a Moroccan woman already has access to shiqa $\bar{q}$, the inclusion of articles 115 and 120 is merely symbolic. According to Jordens-Cotran, the Moroccan legislature wanted to preserve consensual khul' in order to appease conservative opposition to the new law (2007: 338). Given that the Egyptian family law reforms of the 1920 s had served as a source of inspiration for Moroccan PSL reform in the late 1950s (Ghamija 2007: 25), ${ }^{17}$ it is not unlikely that in the early 2000s, the Moroccan legislature, inspired by the Egyptian khul' reform, redefined shiqāq (marital discord). Under the 1993 PSL, women in shiqāq procedures had to establish that marital discord resulted in harm (darar) (Buskens 1999: 156). After the introduction of the 2004 legislation, they no longer needed to do so and it was sufficient to establish marital discord.

17 Both the Egyptian PSL reforms of the 1920s and the Syrian PSL of 1953 were a source of inspiration for the drafters of the Moroccan PSL of 1957-1958. This did not apply to the Tunisian PSL, despite the fact that it was issued shortly before the Moroccan PSL (Ghamija 2007: 25). 
There are important similarities between Egyptian khul' and Moroccan shiqāq. Both require that the spouses appear in court for mediation sessions. Both end the marital relationship in an irrevocable manner within a predetermined period, not to exceed three months in Egypt ${ }^{18}$ and six months in Morocco. There are also important differences. While the Egyptian khul' is clearly reserved for a wife, shiqa $q$ may be requested by either a wife or a husband. Whereas Egyptian women in khul' cases must relinquish their outstanding financial rights and return the dower, Moroccan women in shiqāq cases "only" relinquish their right to $\mathrm{mut}^{\prime} \mathrm{a}$, and only if they initiate the divorce. According to the legal professionals with whom I spoke, a woman does not pay her husband a compensation unless he requests it and is able to prove that she contributed to the marital discord. But whereas the legal professionals I interviewed claimed that this rarely happens, Kruiniger (2015: 190-91) and Loukili (2017: 78) suggest that judges frequently award compensation (indemnité) to husbands who demand it, although they do not make clear how frequently this happens. ${ }^{19}$ Additional research is needed to establish how frequently wives have to pay compensation to their husbands. At this point, it is important to bear in mind that whereas in Egyptian khul' cases compensation is automatic, in Moroccan shiqāq cases it is not (Jordens-Cotran 2007: 349). The differences between Egypt and Morocco led Loukili and Zirari-Devif to conclude that the no-fault divorce rights of Moroccan women are more advantageous than those available to Egyptian women (2004-2005).

\section{Divorce by Agreement}

The $2004 \mathrm{FL}$ also includes a provision that resembles the Moroccan khul' (by agreement) provision. This provision allows men and women to apply for divorce by mutual consent through a procedure called al-țalāq bil'-ittifāq. Unlike khul', however, in al-țalāq bi'l-ittifäq the spouses set the terms and conditions for the divorce themselves, without the involvement of the court, as long as "the interests of children are not harmed" (Article $114 \mathrm{FL} 2004$ ). ${ }^{20}$ According to a woman judge who specialises in al-țalāq bill-ittifäq cases, this means that the

18 The Egyptian provision on khul' mentions that attempts at reconciliation should not exceed three months, without placing any time limit on the entirety of the khul'procedure (Article 20 of Law no. 1/200o). The Moroccan provision on shiqāq is more explicit, stating that "the case should be settled in a period not exceeding six months from the date the petition was filed" (Article 97 FL 2004).

19 For two examples of case law, see Loukili and Zirari (2017: 535-37).

20 The Moroccan al-țalāq bi'l-ittifäq resembles what is often called mubārāàa, which can be initiated by either party and usually requires the wife to renounce her outstanding financial rights rather than pay her husband compensation (Welchman 2007: 112). 
spouses are free to decide whether or not one should pay the other financial compensation. The terms and conditions of the agreement are recorded in writing, either by the spouses at home or in the office of the kātib al-umümi (public clerk), and submitted to the judge. The spouses also must appear in court for mediation. ${ }^{21}$

The introduction of shiqāq and al-țalāq bi'l-ittifäq expanded opportunities for divorce for both women and men in Morocco. Shiqāq and al-țalāq bil-ittifāq became the preferred ways for a woman to end the marital relationship, and consequently the different forms of fault-based divorce and consensual khul almost disappeared from judicial practice (Ministère de la Justice et des Libertés 2012: $8,15,18$ ). Similarly, the relative percentage of men requesting a talāq divorce dropped significantly as men who wished to divorce began to choose shiqāq and al-țalāq bill-ittifāq in high numbers (Ministère de la Justice et des Libertés 2012: 6, 8).

\section{The Divorce Reforms in Practice}

\section{Egypt: Is Khul' a Solution?}

Farafra-Western Desert (Egypt). 21 March 2004. Excerpt from fieldnotes. Late afternoon. It is still hot in the small oasis town. In the shade of a few date palms Hamza, the father of two young children, talks about his failed marriage. While his children are playing in the water, he says that he does not have official custody of his children and yet he is the one who takes care of them. Their mother, his ex-wife, lives far away in Cairo. She does not care about her children. She does not care about him. "She cares about money and that is why she filed a khul' case against me. She could never have won the case, because the prompt dower I registered was very high. In most cases people only register one pound in the marriage contract. I did not. But my wife knew I would repudiate her instead and pay her a lot of money. For the sake of the children, every month I pay 2500 [Egyptian] pounds in order to cover all of her and the children's expenses. But this is still not enough for her!" He apologises for his outburst, saying he does not want to come across as an old man who is complaining. "Many women use khul' to blackmail their husbands, 'If you don't do this, I will drag you into court.' But, it must be said, before the introduction of 
this new [khul $]$ law, a woman who wanted to divorce her husband had to spend years in court before she could get a divorce, if at all. That was very unfair, too."

Hamza's story reflects the gender specific attitude to non-consensual khul' in Egypt. Hamza was from the upper class, but his attitude towards khul'was very similar to that of men from other class backgrounds. Many men believe that women use non-consensual khul' for frivolous and selfish reasons, neglecting their children and destroying their families in the process. And yet, most men also acknowledge that in some cases non-consensual khul' provides women a quick way out of a dysfunctional marriage (see also Al-Sharmani 2017:132). By contrast, the women with whom I spoke often had very positive views on khul' (see also Fawzy 2004: 82-3; Al-Sharmani 2017: 134). They usally claim that the rationale underlying a khul' request was related to a husband's dysfunctional behaviour, very often his unwillingness or inability to provide financial maintenance. Why then, would they apply for a divorce in which they had to relinquish all their financial rights and pay their husbands a compensation rather than file for fault-based divorce?

\section{Is Khul' A Solution for Women?}

Unlike Hamza's ex-wife, the majority of women who request khul' are from a lower-class background (e.g. Sonneveld 2012; Al-Sharmani 2009, 2017). They usually want to divorce because their family has become dysfunctional, for example through spousal abuse, (physical and/or mental), non-provision of maintenance, unemployment, drug addiction, and/or imprisonment, all of which are grounds for a fault-based divorce. In such a divorce, a woman is entitled to keep all of her outstanding financial rights and need not return the prompt dower. In Egypt, however, fault-based divorce was and still is hard to establish. Many cases take two or more years and there is no guarantee that the judge will grant the divorce in the end (Tosson 1999). The cases are not only time consuming but also costly, especially when a woman must travel great distances and miss work to go to court. For a woman whose income depends on the number of hours she works, numerous visits to court pose a heavy financial burden. What became abundantly clear from my interviews with these women is that they had no confidence that establishing grounds for a faultbased divorce would allow them to collect the deferred dower, waiting-period maintenance, and/or mut'a from their husbands. For these reasons, these women argued, if a husband is too poor or simply unwilling to pay maintenance, a no-fault khul' divorce is faster and cheaper. 
Although most women in khul'cases believe that khul' is faster and cheaper, both the consensual and non-consensual khul'require them to pay compensation to their husbands. In the law this compensation is called șadāq (dower). The șadāq is not defined by the law, and thus, in the years immediately following the implementation of khul' in the courts, judges interpreted the șadāq in different ways. Most judges understood the șadāq to be the prompt dower as registered in the marriage contract, but in a considerable number of cases judges understood the șadā $q$ to refer to the deferred dower, and/or the engagement presents, known as qäima ('ayma or qayma in Egyptian Arabic) (Al-Sharmani 2009; Sonneveld 2012). In practice, this means that some women must pay their husbands a deferred dower that they had not yet received, and/or engagement presents that were no longer in their possession, usually because they had been sold during an economic crisis (Sonneveld 2012; Al-Sharmani 2017). Following the decisions of higher courts, judges came to the common understanding that șadāq means prompt dower. ${ }^{22}$ In every Egyptian marriage contract, both the prompt dower and the deferred dower must be registered. Because the registrar (ma'dhün) frequently takes approximately 5 percent of the prompt dower, Egyptian marriage contracts usually specify a symbolic prompt dower, consisting of one Egyptian pound (roughly ten eurocents) or even one-quarter of an Egyptian pound. Since the husband often had registered only one Egyptian pound as prompt dower in the marriage contract, a wife can easily repay this amount, unless her husband objects and asks the judge to open an investigation to establish the real amount he had paid. It should be noted that the situation for upper-class men, such as Hamza, is different, as I will explain later.

Soon after the introduction of the law, the percentage of women requesting a khul' divorce was slightly higher than the percentage of women filing for a fault-based divorce. For example, in 2001 in Cairo, 2695 women requested khul', while 2509 women requested tațilq. Except for the more conservative governorates in the south of Egypt, the numbers in other governorates were similar. In Giza, for example, 1199 and 1125 women requested khul' and tațlīq, respectively. In Alexandria, the numbers were 907 and 825, respectively, and in Sohag (South Egypt) 186 and 352. As in Sohag, the number of tațliq divorces remained higher than the number of khul'requests in Egypt south of Cairo (Sulīmān and Șalāh 2003: 18-28).In 2014, the Egyptian Central Agency for Public Mobilisation

22 In a random selection of ten khul' court rulings, issued in February 2016 in a Cairene courthouse, the șadāq is defined as the amount of prompt dower registered in the marriage contract. If the husband disputes the amount returned to him, he can file a separate case. 
and Statistics (CAPMAS) established that the percentage of fault-based cases comprised a little over one-third of the total number of khul' cases that were concluded (Al-Sharmani 2017: 89).

A significant number of women, like Hamza's ex-wife, cancelled their khul' lawsuits. For example, in the Northern governerates of Qalyubiya and Gharbiya, of the 72 and $196 \mathrm{khul}$ ' cases that were filed, 20 and 43 were cancelled, respectively. ${ }^{23}$ The reasons for the cancellations varied, ${ }^{24}$ but women frequently said that they hoped to pressure husbands into changing their behaviour by threatening them with a divorce against their will through khul'. This usually meant that wives wanted their husbands to start paying maintenance (again) or that they wanted them to pronounce the taläq. These women took advantage of many a man's fear that his wife can turn him into a makhlü', an issue to which I now turn.

\section{Is Khul' A Solution for Men?}

As noted by de Hart, Sonneveld and Sportel (2017), the literature on gender and legal rights in Muslim-majority countries has overwhelmingly focused on the legal rights of Muslim women, usually in the field of divorce. Men are depicted as authoritarian, and as having power and privilege over women. This, however, is not always consistent with how men such as Hamza perceive of the power balance in marriage. During my fieldwork in both Egypt and Morocco, most men with whom I spoke stated that legal reforms in the areas of divorce, custody, and $r u^{\prime} y \bar{a}$ (visitation) give wives more power over their husbands. According to Al-Sharmani (2017) and Žvan Elliott (2015), who conducted fieldwork research in Egypt and Morocco, respectively, men claim that the PSL reforms are emasculating them. This explains why some men, such as Hamza, respond to their wives' khul' request by pronouncing the taläq. Thinking that divorce is the prerogrative of the husband, they prefer to save their honour over divorce against their will.

As noted, the introduction of non-consensual khul' provoked much controversy in Egypt. In Egyptian society, the term makhlü'suggests that the process by which a husband is divorced by his wife is like that of a dentist who pulls a bad tooth. ${ }^{25}$ In the first years following the introduction of the divorce reform

23 This information is based on statistics provided to the author by the Association for the Development and Enhancement of Women (ADEW) in August 2004. Statistics on file with author.

24 Reasons stated included: procedural mistakes and women pressured by relatives to withdraw their cases.

25 The term makhlü derives from the verb khala'a, which means to take off (a garment, a tooth). 


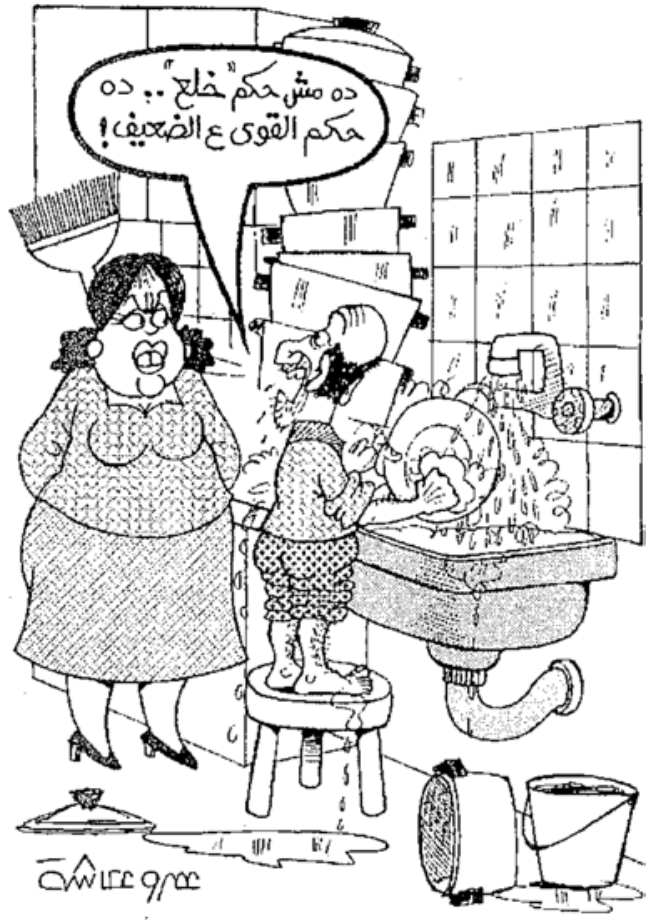

FIGURE 1

"The Ruling of the Strongest." The husband says to his wife: "This is not a khul'ruling, this is the ruling of the strong over the weak!" Amr Okasha, Al-Wafd, January 31, 2000

in January 2000, cartoons were a very popular way of depicting the disastrous effects of khul'on men's honour and masculinity. In the cartoons, we see men who are pregnant, pushing babies in strollers, and dominated by their wives (see further Sonneveld 2012: Chapter 3).

The stigma attached to a divorce through khul' gives women a powerful tool for negotiating the terms of the marital relationship. Several women whom I interviewed stated that they use khul' as a strategy to pressure their husbands to change their behaviour and to compel them to pay maintenance. Some women go so far as to file a khul' case in court, only to cancel it as soon as her husband concedes to her wishes, as the interview fragment with Hamza presented at the beginning of this section makes clear.

Significantly, in the same period, a smaller number of cartoons painted a different picture. In Figure 2, we see a husband walking out of the family court. Although his wife has divorced him through khul', he is neither stigmatised nor emasculated. Instead, he emerges triumphant, carrying a sack full of money, the șadāq, which his wife returned to him as compensation for the divorce and which he might use to remarry. 


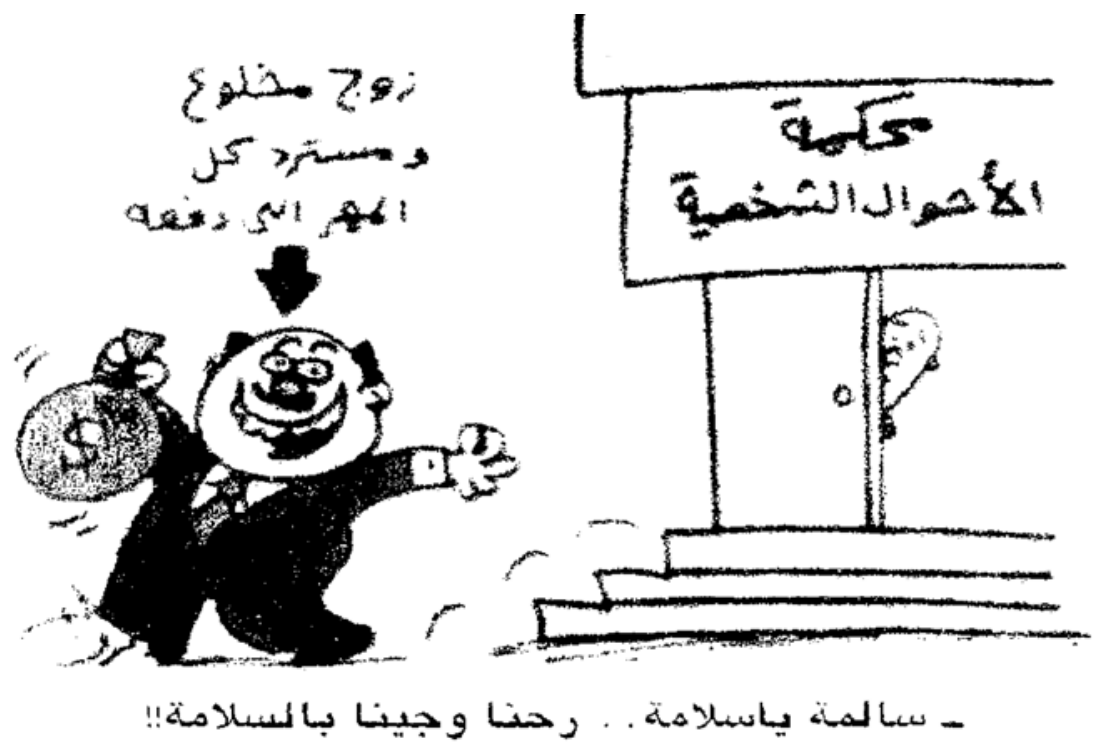

FIgURE 2 "A Husband Walks out of the Personal Status Court." Amro Selim, Rose al-Yusuf, March 13-19, 2004

As noted in section 1, an Egyptian husband who wishes to divorce has one legal option to do so: talāq. This right of a husband, however, also implies a duty to pay his wife maintenance during the waiting period, deferred dower, and at least two years of mut'a compensation, if she is not responsible for the divorce. He must also provide suitable housing for her "if they have children." Because a țalāq divorce is expensive, it is not unusual for a husband to push his wife into a khul' so he can divorce her cheaply and use the money to marry another woman and pay a new dower. According to Tucker, Ottoman judges were aware of this male strategy and tried to verify whether a woman had made the khul request of her own free will or had been pressured into it (1999: 99). Similarly, in Marinid Morocco, husbands sometimes pressured their wives into khul'(Admiral 2016: 127). Under the Moroccan $2004 \mathrm{FL}$, a woman who can establish that she was pressured into requesting a khul' is entitled to the return of the compensation payment (Article 117). When I asked three Egyptian judges if they were concerned that women might be pressured to ask for khul', they acknowledged that husbands sometimes use khul' to their advantage, but they stated that it is not their duty to make such a determination. Heavy judicial caseloads play an important role in the reluctance of judges to investigate whether a woman was pressured to make a khul' request (Sonneveld 2012: 126-27). In some cases, as suggested in the cartoon in Figure 2, the reluctance of a judge to 
investigate whether a wife truly wants khul' makes it possible for a husband to divorce cheaply, and to demand that his wife return more than the prompt dower he had given her.

An Egyptian husband has always had the opportunity to pressure his wife into a khul' divorce out of court, usually on terms detrimental to her financial security and that of her children. The introduction of judicial khul' and the legal requirement to return "only" the prompt dower place a limit on excessive financial demands by husbands. In some cases, wives involved in khul' court cases may even walk out of such a marriage by returning the one Egyptian pound registered in the marriage contract, when, in fact, the husband had contributed more. The situation for upper class women is different. As the interview with Hamza, the divorced father, makes clear: upper class men do not register a symbolic prompt dower. Elite husbands to be (and their families) want to display their wealth, and registering a high prompt dower is part of this strategy. Consequently, in khul' divorce cases, upper-class women usually will have to return a higher prompt dower than their lower and middle class counterparts.

In the continuation of our conversation, Hamza told me that the Egyptian khul' is not Islamic because, if it were, non-consensual khul'would be practiced in Saudi Arabia. Thus, Hamza concluded, the only reason we have khul' in Egypt is because some of Suzanne Mubarak's female friends wanted to get rid of their husbands, a view that was widespread in Egypt at the time (Fawzy 2004; Sonneveld 2012: Chapter 2). One of the main objections to khul' in the Egyptian public debate is that the procedure is designed for rich elite women who can afford to return the șadā $q$ (dower). In the authoritarian Egyptian political context, many males feel that the interests of the powerful few prevail over those of the powerless majority, and that the government is interfering in the only domain where some men retain their authority: the family.

Between 2000 and 2008, the Egyptian parliament approved a number of additional PSL reforms. While the level of public debate never reached that of khul', the reforms significantly altered the legal position of husbands and wives in marriage. In January 2000, a legal reform permitted Egyptian women to travel without the consent of their husbands. ${ }^{26}$ In 2005, the maternal custody age was raised from ten for boys and twelve for girls to fifteen for both boys and girls. Above these ages, the law gives the child the right to choose whether to

26 In November 2000, the Egyptian High Constitutional Court passed a ruling that gives Egyptian women the right to request a passport without the need to establish, in writing, the agreement of their husbands. Legal professionals interpret this ruling as implicitly authorising a wife to travel without the consent of her husband. 
stay with its mother (without custody fees) or father. ${ }^{27}$ In 2008, a new law gave divorced women with custody of children the right to educational guardianship (al-wilāya al-ta'limiyya) (i.e. the supervision of children's choice of school), a legal reform that is unparalleled in the Muslim world, except for Tunisia (Article $67 \mathrm{PSL}$ ). Based on the claim that the educational guardianship reform violates the principles of Islamic shari ${ }^{\prime} a$ as enshrined in Article 2 of the Egyptian constitution, claimants asked the High Constitutional Court to evaluate the constitutionality of the provision in 2010. In March 2016, the High Constitutional Court ruled that the provision on educational guardianship is constitutional. ${ }^{28}$

When an authoritarian government introduces legislation that enhances women's legal rights with regard to the family but does not reform men's legal rights inside that same family, it is not surprising that when political oppression is lifted, disenfranchised men will try to abolish the laws that expanded their wives' freedom and curtailed theirs (Sonneveld 2017: 101). After the Egyptian uprising of 25 January 2011, numerous organisations for the rights of divorced fathers gained public prominence. These organisations almost succeeded in turning back the family law reforms, but in June 2012 Parliament was dissolved and their demands were shelved (for more details, see Sonneveld and Lindbekk 2015). If anything, the vocal grassroots activism of divorced fathers indicates that a decade of PSL reform in Egypt has had a great impact on the position of husbands and fathers inside a (broken) family. Their wives can divorce them at will, their children may remain with the mother until at least the age of fifteen, and they have lost their position as the educational guardians of their children.

It would be a mistake, however, to conclude that Egyptian men, in particular, or Middle Eastern men, in general, are or want to be male patriarchs, or, as my male interlocutors often call it: "Si Sayyids" - referring to a character in Naguib Mahfouz's trilogy who punished his wife for leaving the house without his permission to visit the shrine of a saint. Almost all of the fifty men interviewed by Al-Sharmani in Cairo reported that what they want most in marriage is istiqrār, that is to say, emotional and financial stability with a partner to

27 In December 2016, there was much online discussion in Egypt about a PSL amendment proposed by a female member of parliament, which would transfer custody of children to the father in cases in which the mother remarries. For details, see Barlamānī 24 November 2016, accessed 14 December 2016. Under the current PSL, the mother of the mother is the first in line to exercise custody of children when her divorced daughter remarries. A few weeks later, the member of parliament denied that her proposal would transfer custody of children to the father in case of remarriage of the mother. For details, see Al-Yawm alSābi' 8 December 2016, accessed 14 December 2016. 
whom they are romantically attached (2017: 155) ${ }^{29}$ Anthropological studies demonstrate that there are different styles of masculinity in the Middle East, and that many men are very committed and emotionally involved husbands and fathers (Inhorn 2012: 32).

Love and intimacy, however, do not mean that idealised notions of what it means to be a man (and a woman) have changed, in particular the notion that a husband should be the breadwinner and, in return, his wife must be an obedient housewife and mother. For example, Al-Sharmani found that love and attachment manifest themselves within economic and social structures that often sustain gender-based inequalities and hierarchies (2017: 116; see also Sonneveld 2012: Ghannam 2013; Žvan Elliott 2015). While the fifty Cairene men interviewed by Al-Sharmani value istiqrär most in marriage, almost all of them regard non-consensual khul' as a threat that adds more challenges to existing problems of marriage (2017: 130). For example, many husbands find it difficult to reconcile social and legal expectations, which define them as independent breadwinners and their wives as dependent caretakers, with a reality in which these roles are sometimes inversed (Al-Sharmani 2017: 125-30; see also Sonneveld 2012). Threatened by this conundrum, Hamza decided to save his honour and divorce his wife through what he perceived to be a male prerogative: țalāq.

In conclusion, my analysis reveals two important observations concerning the way women and men in Egypt divorce in the period following the 2000 khul' divorce reform. First, non-consensual, no-fault khul' has become the favourite means for Egyptian Muslim women to divorce. Second, most men experience $k h u l '$ as a stigmatising experience, and some prefer to pronounce the talā $q$ instead. In the next section, we will see whether the same observations hold for Morocco, where, in 2004, women were also given the legal possibility to request a non-consensual, no-fault divorce through shiqāq. In contrast to Egypt, however, in Morocco both men and women can request shiqāq, with men using it in such large numbers that the number of filed taläq cases has declined.

\section{Morocco: Is Shiqāq a Solution?}

Fes-Boulemane: Fes (Morocco). 15 April 2015. Excerpt from fieldnotes. Latif, a man in his forties, is waiting in front of the courtroom. After a marriage of fifteen years, his wife decided to invoke shiqāq. Against his

29 Between 2008 and 2010, Al-Sharmani interviewed fifty men and fifty women in greater Cairo who were in different stages of marital relationships. Most of them were from middle- and low middle-class backgrounds (2017: 112). 
will. They have two young children. He explains that his wife has a good job and since he has always had difficulties finding a steady job, he does most of the childrearing and household chores. She is determined to divorce him and is willing to renounce all of her financial rights, but and his tone changes - she insists on custody of the children. "Under the new law," Latif says, "the children will remain in her custody until the age of fifteen. Fifteen!" In desperation, he continues: "According to the law, I have to leave the marital home and rent an apartment. The only legal right I have is to see my children a few hours every Sunday. I will miss my children a lot." He starts to cry softly.

\section{Is Shiqāq a Solution for Women?}

Before 2004, a Moroccan woman who wanted a divorce could request either tațliq or consensual khul'. As in Egypt, the reformed $2004 \mathrm{FL}$ provided solutions for a woman who could not prove cause in court and/or whose husband either did not agree to khul' or demanded a compensation in return for khul' that was more than the woman could afford. Article 120 of FL 2004 gives these women the right to invoke the irreconcilable differences procedure, shiqa $\bar{a}$, in which a judge determines the financial rights to be paid by establishing the contribution of each spouse to the breakdown of the marriage (Article 97 FL 2004).

The judges I interviewed claimed that, initially, women who requested a shiqa $\bar{a} q$ dissolution retained their rights to the dower, nafaqa, and $m u t^{\prime} a$, unlike their Egyptian counterparts, who must renounce these rights. In 2010, the Court of Cassation in Rabat issued a ruling declaring that a woman who initiates shiqa $\bar{q}$ will not receive mut'a. ${ }^{30}$ The court reasoned that mut' $a$ can be awarded only in cases in which the husband initiates the talāq or the shiqa $q .{ }^{31}$ If a woman requesting shiqāq claims that her husband is the main cause of marital strife, she can claim compensation $\left(\operatorname{ta}^{\prime} w \bar{w} d\right)$, and the same applies to a husband who claims that his wife is responsible for the marital discord. Moreover, after the wife has initiated the shiqāq divorce, it is her responsibility to collect her outstanding rights, such as the deferred dower, from her husband. These constraints do not deter women from filing shiqāq cases. In 2011, the overwhelming majority of wife-initiated divorce cases nationwide were shiqāq

30 Several judges (males and females) told me that they approved this ruling because they deemed it unfair that women were granted mut'a compensation in the first years following the introduction of shiqāq. Some judges opposed the practice of denying women in women-initiated shiqāq case this compensation. See, for example, the elaborate annotation of judge 'Adil Hamidi, head of the Court of First Instance, Essaouira, on the website Maroc Droit (published 15 April 2014, accessed 8 June 2018).

Ruling no. 433, 21 September 2010. 
cases (22,008), ${ }^{32}$ followed by al-țalāq bi'l-ittifāq (7000), ${ }^{33} \mathrm{khul}^{\prime}$ (4147), and tațtīq li-ghayba (absence) (563) (Ministère de la Justice et des Libertés 2012: 8, 15, 18). My analysis of court records from nine courts across the country confirms that consensual khul', which was the default option for women before the $2004 \mathrm{FL}$ reform, and fault-based divorce, are in sharp decline. Almost all divorce cases initiated by women are either shiqāq or al-țalāq bi'l-ittifāq, which, as noted, differ from khul' in that compensation is not automatically required. In the nine courts I visited, of more than 2000 divorce requests made by women in May 2014, only two were khul' divorces. To illustrate, a kātib (clerk) in a courthouse in the Fes-Boulemane region said that he had not registered a single khul' request in two years. The procedure, he said, had become extinct (mundarisa). ${ }^{34}$ Although most women with whom I spoke requested shiqa $q$ for reasons that make them eligible for a fault-based divorce, ${ }^{35}$ like their Egyptian counterparts, they prefer a non-consensual, no-fault divorce procedure because it is faster than fault-based divorce. Financially independent women, such as Latif's wife, do not care much about their financial rights and are prepared to give them up completely.

The popularity of women-initiated al-țalāq bi'l-ittifāq merits attention. More research is needed to find out the most common reasons behind the popularity of this newly introduced option for divorce. My observations in a large provincial courthouse in the Meknes-Tafilalt legal district clearly showed that couples in al-țalāq bi'l-ittifā $q$ cases interacted with each other in a number of different ways. In some cases, both spouses brought members of their extended families into the courtroom, while in other cases only one of the spouses brought family members while the other spouse (usually the husband) came alone. In other cases, both spouses came alone. When in the presence of family members of both sides, the spouses usually behaved respectfully to each other, but in cases in which the husband came alone and the wife was accompanied by family, the relationship was sometimes quite tense. In one case, in which both spouses came alone, the husband angrily walked out of the

32 This number is based on the following calculation. The total number of settled shiqāq cases in 2011 was 32,365 . Of the total number of shiqāq cases registered in 2011 (settled and pending), 68 percent were initiated by women (Ministère de la Justice et des Libertés 2012: 16, 18). Although it is not clear whether this percentage also applies to the percentage of settled shiqāq cases that were initiated by women, I used this percentage to calculate the number of women who actually divorced through shiqāq.

The total number of settled cases in 2011 was 12,209 (Ministère de la Justice et des Libertés 2012: 6, 8). On the basis of my conversations with family law judges, I estimate that approximately 60 percent of all al-țalāq bill-ittifāq cases were initiated by women.

34 Informal conversation with a clerk (kātib kitāba al-ḍabț), 23 April 2015.

35 The most common reason is the non-provision of maintenance by the husband. 
courtroom immediately after the judge had closed his and his wife's case for that day. In all of these instances, spouses probably had different reasons for opting for al-țalāq bill-ittifā $q$, and it was likely that this "consensual" divorce was not always completely consensual. For example, during my fieldwork, judges, lawyers and litigants claimed that sometimes a husband makes his demands reasonable, so as to prevent his wife from resorting to a more expensive and stigmatising shiqāq divorce against his will. In these cases, the introduction of shiqā $q$ has given women a powerful tool to negotiate the terms of marriage dissolution. In most cases, however, my interlocutors claimed that spouses wish to end the relationship on amicable terms to avoid the stigma that may arise from a contested divorce, for their own sake but also for the sake of the children, or to maintain good relations with the ex-partner's inlaws, especially when the spouses belong to the same extended family.

\section{Men Divorced Against Their Will}

In the interview excerpt presented earlier, Latif, the divorced father, was divorced against his will through shiqāq. The divorce had several consequences. First, by law Latif was required to pay his wife her deferred dower and the waiting-period maintenance, and, second, he had to give up custody of his children. During the interview with me inside the courthouse, Latif did not talk much about the financial consequences of the divorce, despite the fact that he had difficulties in securing a steady stream of income. His indifference was probably related to the fact that his wife, who was the main breadwinner, was prepared to renounce her right to the deferred dower and waiting-period maintenance. The extent to which this practice is common is not clear to me. Given that most women prefer a speedy shiqa $q$, there is reason to expect that wives with fewer economic resources would prefer to renounce their outstanding financial rights rather than spend much time on collecting them, something which, judges admit, can be hard. Further research is needed to determine whether these women attempt to establish grounds retroactively in order to receive compensation from their ex-husbands. As noted earlier, this was common practice in khul' cases in Marinid Morocco (Admiral 2016: 124).

Second, Latif was moved to tears by the prospect of losing the right to be intimately involved in the care and upbringing of his young children. During their marriage, his wife had held a well-paid job while he had assumed responsibility of most of the childcare and household chores. According to the 1993 Moroccan PSL, it was a husband's duty to provide maintenance for his wife and children and for a wife to be an obedient mother and housewife. Although this provision was amended in 2004, giving husbands and wives equal responsibility for the supervision of the family (Article 4 FL 2004), this does not mean that 
households such as Latif's, in which the wife works outside the home and the husband inside the home, are common. And yet, they are not an exception. The variation in the division of labour in Moroccan households is not reflected in the 2004 PSL reform. In the event of divorce, custody is no longer the duty of both parents (Article 164 FL 2004), but passes to the mother, with the father second in line (Article 171 FL 2004).

In general, it is hard for a father to gain legal custody of his children. ${ }^{36}$ In a courthouse in the Middle Atlas Mountains, my research assistant and I met with a father who had filed a lawsuit demanding custody of his teenage daughter. The girl's biological mother was a prostitute with whom her father had had a sexual relationship. After a DNA test proved that he was the biological father, he acknowledged the girl in court and took care of her, both financially and emotionally. He did not object to the girl's living with her mother, until he learned that the mother was training the girl to become a prostitute too. Over the course of a few months, we witnessed how he tried to gain custody of his daughter and bring her into his household, to no avail.

Apart from cases where fathers try to gain custody of their children, there are also divorced Egyptian and Moroccan fathers who were confronted with custody of their children against their will. Men like Hamza feel that they have no choice but to shoulder the daily responsibility of childcare tasks in the face of mothers for whom child custody is more of a burdensome duty than a right. In most cases, divorced mothers claim they lack the financial resources to care for their children's daily needs and they think that the children will be better off with their fathers (see also Vatuk, this volume). In the Egyptian oasis, surrounded by his children, Hamza accused his ex-wife not only of neglecting their offspring, but also of being greedy. Despite the fact that he was the actual caregiver for their children, he had to pay her large sums of child maintenance every month because she had legal custody of them.

The stories of the Moroccan and Egyptian fathers presented in this essay do not necessarily mean that perceptions regarding the gendered nature of the spousal roles are changing. In her research in Cairo, Al-Sharmani noted that the majority of the fifty men and fifty women that she interviewed still regard childcare (and housework) as the main responsibility of the wife (2017: 130), despite the fact that many of these women work outside the home. The stories presented here point to an empirical reality that has been largely ignored, both by academics and by legislators. In both countries, legislators introduced legal reforms that make it easier to divorce, without introducing custody reforms

$3^{6}$ If the mother custodian remarries, custody of children older than seven years of age passes to the father (Articles 174 and 175 FL 2004). 
that reflect the multifaceted types of post-divorce childcare arrangements in Moroccan and Egyptian society.

\section{Is Male-Initiated Shiqāq a Solution for Men?}

Whereas in Egypt, non-consensual, no-fault divorce reform is open only to women, in Morocco it is open to both men and women. The introduction of shiqāq and al-țalāq bi'l-ittifāq changed the divorce patterns and strategies of both Moroccan women and men. In 2011, approximately 32 percent of the 32365 shiqāq cases (10357) and approximately 40 percent of the 12209 al-talāq bil-ittifāq (5000) cases were raised by husbands. ${ }^{37}$ By comparison, the number of talāq divorces was 2310 (Ministère de la Justice et des Libertés 2012: 6, 8). Interviews with judges reveal that husbands favour shiqāq over talāq for two reasons. First, țalāq requires a husband to deposit the deferred dower, waitingperiod maintenance, and mut' $a$ in the courthouse safe within a period not exceeding thirty days from the date of the final attempt at mediation (Article 83 FL 2004). A judge will authorise a husband to register the repudiation only after he has paid the deposit (Article $87 \mathrm{FL}$ 2004). By contrast, in husband-initiated shiqāq cases, the divorce is not conditional on the husband's first depositing the amount due to the wife. If, for whatever reason, a husband fails to deposit the required sum of money, the wife must collect the money owed by returning to court. However, judges claim that this practice in shiqāq cases came to an end after husbands were required to pay their financial obligations to the court before receiving judicial authorisation to register the divorce.

Even after this judicial intervention, husbands continued to file for shiqāq rather than for talāq. In a talā $q$ case, the husband must wait for the 'idda period to end before the divorce becomes final, while in a shiqāq case the divorce occurs immediately and is irrevocable (Article $123 \mathrm{FL}$ 2004). A male-initiated shiqāq is also cheaper than țalāq as a husband does not pay his wife mut'a. According to the judges I interviewed, Moroccan men, like women, prefer to separate on amicable terms through al-țalāq bi'-ittifāq, and, when this proves difficult, they want to divorce as cheaply and quickly as possible through shiqāq.

Between $3^{-}-35$ percent of the requests for shiqā $q$ are made by husbands. This percentage is based on statistics provided by the Moroccan Ministry of Justice and Liberties. The statistics show that, in 2010, 34 percent of requests for shiqāq were made by husbands. In 2011, this number fell to 32 percent (Ministère de la Justice et des Libertés 2012: 18). On al-talāq bil-ittifāq, see the calculation in footnote 33 . 


\section{Conclusion}

Over the last two decades, legislators and ruling elites in many Arab states have tried to bring women's rights to divorce in line with those of men through the introduction of no-fault divorce at the demand of the wife. Egypt and Morocco, which introduced khul' and shiqa $q$ in 2000 and 2004, respectively, were pioneers in this regard. In this essay, I compared the rights and duties of both men and women with regard to divorce in Egypt and Morocco. I posed two questions: First, how do men and women navigate the different pathways to divorce and, second, are there differences between the two countries in the way they try to obtain a divorce?

In Egypt, many opponents to the khul' divorce reform claimed that it would only be an option for rich women who could afford to renounce their outstanding rights and return the dower. In practice, however, non-consensual, no-fault divorce usually has little economic cost for women in Egypt. The same applies to women in Morocco. Even though Egyptian and Moroccan women must give up (some of) their financial rights and must (sometimes) compensate their husbands, the financial and mental costs of prolonged litigation, with no guarantee that a divorce will be obtained in the end, make khul' and shiqāq the most common way for women to end their marriages.

The introduction of the Moroccan non-consensual, no-fault shiqāq divorce has reduced the relative and absolute number of Moroccan husbands who request a talā $q$ divorce. When opportunities for divorce increase for both men and women, as happened in Morocco, both spouses prefer to separate either on amicable terms (al-talāq bil'-ittifāq) or to divorce as quickly and cheaply as possible through a procedure that leads to a fast, guaranteed, and irrevocable result. In Egypt, however, only women have been given increased opportunities for divorce. The lack of increased divorce opportunities for Egyptian husbands may account for the emergence in the mid-20oos of organisations for the rights of divorced fathers. The main aims of these small but vocal organisations are to change khul' from a non-consensual to a consensual procedure, and to give fathers more legal rights to see their children.

The impact of family law reform on husbands and fathers has largely escaped the attention of scholars working on gender in the Middle East, despite the growing number of ethnographic studies of courts. In this essay I have argued that gender should no longer be analysed exclusively in terms of women's interests. A full gender analysis will make it possible to gain a more detailed understanding of the impact of legal reform on the lives of both men and women. According to Charrad, the core mandate of scholarship on gender in the Middle East is "to dismantle the stereotype of the silent, passive, 
subordinate, victimized, and powerless Muslim woman" (2011: 418). The time has now come for scholars to challenge the stereotype of the controlling, dominant, and oppressive Arab man and to demonstrate that husbands and fathers have a wide range of relationships with their wives and children. Hamza and Latif, the Egyptian and Moroccan fathers discussed in the two case studies, bore the main responsibility for childrearing and nurturing. This aspect of daily life is not reflected in current Egyptian and Moroccan personal status law. For these men, divorce can come at a high price.

\section{References}

Admiral, Rosemary. 2016. "Women and Islamic Law in Marinid Morocco." PhD dissertation: University of Illinois.

Al-Akhrīsī, Su'ād. 2005. Min mudawwana al-ahwāl al-shakhșiyya ilā mudawwana al-usra: masār al-ta'adīlāt wa muțālib al-ḥaraka al-nisāityya. Al-Ribāṭ: Dār al-Salām.

Ansay, Tuğrul and Don Wallace, Jr. 2005. Introduction to Turkish Law. The Hague: Kluwer Law International.

Bernard-Maugiron, Nathalie. 2004. "Quelques développements récents dans le Droit du statut personnel en Égypte," Revue internationale de droit comparé 2:355-85.

Buskens, Léon. 1999. Islamitisch Recht en Familiebetrekkingen in Marokko. Amsterdam: Bulaaq.

Buskens, Léon. 2003. "Recent Debates on Family Law Reform in Morocco: Islamic Law as Politics in an Emerging 'Public Sphere,", Islamic Law and Society 10 (1): 70-131.

Charrad, Mounira M. 2011. "Gender in the Middle East: Islam, State, Agency," Annual Review of Sociology 37: 417-37.

Ebert, Hans-Georg. 2010. Die Qadrî-Pâshâ-Kodifikation: Islamisches Personalstatut der Hanafitischen Rechtsschule. Frankfurt am Main: Peter Lang GmbH.

El-Ehwany, Hossam. 2012. "Le droit Égyptien de la famille." In: Nathalie Bernard-Maugiron and Baudouin Dupret (eds.) Ordre public et droit musulman de la famille en Europe et en Afrique du Nord. Brussels: Bruylant, 29-69.

Fawzy, Essam. 2004. "Personal Status Law in Egypt: An Historical Overview." In Lynn Welchman (ed.), Women's Rights and Islamic Family Law: Perspectives on Reform. London and New York: Zed Books, 30-44.

Feminists, Insha'allah! The Story of Arab Feminism. DvD. Directed by Feriel Ben Mahmoud. New York: Women Make Movies, 2014.

Ghamīja, 'Abd al-majīd. Mawqif al-majlis al-'alì min thanāilya al-qānūn wa-l-fiqh $f \grave{\imath}$ masāil al-ahwāl al-shakhșiyya. Al-Ribāț: Jam'iyyat al-malūma al-qānūniyya wa-lqaḍāisyya. 
Ghannam, Farha. 2013. Live and Die Like a Man: Gender Dynamics in Urban Egypt. Stanford: Stanford University Press.

De Hart, Betty, Sonneveld, Nadia and Iris Sportel. 2017. "New Perspectives on Gender in Shari'a-Based Family Law Studies: Moving Beyond the Women's Issue," Religion and Gender 7 (1), 42-52. DoI: <http://doi.org/10.18352/rg.10210>.

Inhorn, Marcia C. 2012. The New Arab Man: Emergent Masculinities, Technologies, and Islam in the Middle East. Princeton: Princeton University Press.

Ivanova, Svetlana. 1996. "The Divorce Between Zubaida Hatun and Esseid Osman Aga." In Amira El Azhary Sonbol (eds.) Women, the Family, and Divorce Laws in Islamic History. Syracuse: Syracuse University Press, 112-25.

Loukili, Mohamed. 2017. "La jurisprudence marocaine relative à l'application de Code de la famille." In Marie-Claire Foblets (eds.) Le code marocain de la famille en Europe: Bilan comparé de dix ans d'application. Brussels: La Charte, 69-86.

Loukili, Mohamed and Michèle Zirari(-Devif). 2004-2005. "Le nouveau code marocain de la famillie: une réforme dans la continuité." Yearbook of Islamic and Middle Eastern Law 11 (2004-2005): 205-18.

Loukili, Mohamed and Michèle Zirari(-Devif). 2017. "Jurisprudence marocaine." In Marie-Claire Foblets (eds.) Le code marocain de la famille en Europe: Bilan comparé de dix ans d'application. Brussels: La Charte, 495-576.

Jordens-Cotran, Leila. 2007. Nieuw Marokkaans Familierecht en Nederlands IPR. The Hague: Sdu Uitgevers.

Kruiniger, Pauline. 2015. Islamic Divorces in Europe: Bridging the Gap between European and Islamic Legal Orders. The Hague: Eleven International Publishing.

Ministère de la Justice et des Libertés. 2012. Statistiques des sections de la justice de la famille. Année 2011. Rabat: Ministère de la Justice et des Libertés.

Mir-Hosseini, Ziba. 2000. Marriage on Trial: Islamic Family Law in Iran and Morocco. London: I.B.Tauris.

Rapoport, Yossef. 2005. Marriage, Money and Divorce in Medieval Islam. Cambridge: Cambridge University Press.

Sezgin, Yüksel. 2013. Human Rights under State-Enforced Religious Family Laws in Israel, Egypt and India. New York: Cambridge University Press.

Shaham, Ron. 1997. Family and the Courts in Modern Egypt, A Study Based on Decisions by the Sharīa Courts, 1900-1955. Leiden: Brill.

Shaham, Ron. 1999. "State, Feminists and Islamists: The Debate over Stipulations in Marriage Contracts in Egypt," Bulletin of the School of Oriental and African Studies $62(3): 462-83$.

Al-Sharmani, Mulki. 2009. “Egyptian Family Courts: A Pathway of Women's Empowerment?" Hawwa 7 (2): 89-110.

Al-Sharmani, Mulki. 2017. Gender Justice and Legal Reform in Egypt. Cairo: American University in Cairo Press. 
Singerman, Diane. 2005. "Rewriting Divorce in Egypt: Reclaiming Islam, Legal Activism, and Coalition Politics." In Robert W. Hefner (eds.) Remaking Muslim Politics: Pluralism, Contestation, Democratization. Princeton, N.J.: Princeton University Press, 161-88.

Sonbol, Amira. 1995. "Modernity, Standardization, and Marriage Contracts in Nineteenth Century Egypt." In Daniel Panzac (eds.) Histoire économique et sociale de l'Empire ottoman et de la Turquie (1326-1960): Actes du Sixième Congrès International Tenu à Aix-en-Provence du rer au 4Juillet 1992. Paris: Peeters, 485-96.

Sonneveld, Nadia. 2012. Khul' Divorce in Egypt: Public Debates, Judicial Practices, and Everyday Life. Cairo and New York: American University in Cairo Press \& Oxford University Press.

Sonneveld, Nadia. 2017. "From the Liberation of Women to the Liberation of Men? A Century of Family Law Reform in Egypt," Religion and Gender 7 (1), 88-104. DOI: <http://doi.org/10.18352/rg.10197>.

Sonneveld, Nadia and Monika Lindbekk. 2015. "A Counter-Revolution in Egyptian Family Law?" New Middle Eastern Studies, 5, <http://www.brismes.ac.uk/nmes>.

Sonneveld, Nadia and Erin Stiles. 2016. "Divorce and Custody: Contemporary Practices: Khul'." In Suad Joseph (eds.) Encyclopedia of Women \& Islamic Cultures. Leiden: Brill.

Sonneveld, Nadia and Ahmed Tawfik. 2015. "Gender, Islam and Judgeship in Egypt," International Journal of Law in Context 11 (3): 341-6o.

Sulīmān, 'Azza and 'Azza Ṣalāḥ. 2003. "Al-khul' qānūnān wa-tațbīqān." In: Aḥmad alṢāwī (eds.) Al-ḥaṣād: 'amayn 'alā al-khul'. Al-Q̨āhira: Markaz qạ̣āyān al-mar'a almașriyya, 13-28.

Tosson, Nefertiti. 1999. Women in Personal Status Courts: A Field Study. Cairo: Arab Alliance for Women.

Tucker, Judith E. 1999. In the House of the Law: Gender and Islamic Law in Ottoman Syria and Palestine. Cairo: American University in Cairo Press.

Welchman, Lynn. 2007. Women and Muslim Family Laws in Arab States: A Comparative Overview of Textual Development and Advocacy. Amsterdam: ISIM/Amsterdam University Press.

Zantout, Mida R. 2006. "Khul': Between Past and Present," Islamic Law and Law of the Muslim World. Paper 08-14. New York: New York Law School.

Zilfi, Madeline C. 1997. "We Don't Get Along: Women and Hul Divorce in the Eighteenth Century." In Madeline C. Zilfi (eds.) Women in the Ottoman Empire. Leiden: Brill, 264-96.

Žvan Elliott, Katja. 2015. Modernizing Patriarchy: The Politics of Women's Rights in Morocco. Austin, Texas: The University of Texas Press. 